\title{
Models and Tools for Managing Distributed Software Development: A Systematic Literature Review
}

\author{
Catarina Costa \\ Centro de Informática \\ Universidade Federal \\ de Pernambuco \\ (CIn - UFPE) \\ Recife, PE, Brasil \\ csc@cin.ufpe.br
}

\author{
Camila Cunha \\ Centro de Informática \\ Universidade Federal \\ de Pernambuco \\ (CIn - UFPE) \\ Recife, PE, Brasil \\ ccb2@cin.ufpe.br
}

\author{
Rodrigo Rocha \\ Centro de Informática \\ Universidade Federal \\ de Pernambuco \\ (CIn - UFPE) \\ Recife, PE, Brasil \\ rgcr@cin.ufpe.br
}

\author{
A. César C. França \\ Centro de Informática \\ Universidade Federal \\ de Pernambuco \\ (CIn - UFPE) \\ Recife, PE, Brasil \\ cesarfranca@gmail.com
}

\author{
Fabio Q. B. da Silva \\ Centro de Informática \\ Universidade Federal \\ de Pernambuco \\ (CIn - UFPE) \\ Recife, PE, Brasil \\ fabio@cin.ufpe.br
}

Rafael Prikladnicki

Faculdade de Informática

Pontifícia Universidade

Católica do Rio Grande do Sul

(FACIN-PUCRS)

Porto Alegre-RS

rafaelp@pucrs.br

Background: In the last decade, it was possible to notice a significant increas e in Distributed Software Development approach (DSD). Objective/Method: This research aimed to identify effective models and tools for supporting the DSD management through a systematic literature Review. Results/Conclusion: 25 primary studies reveal that since 2000 , the number of studies on DSD has significantly increased, while only few tools have been developed. Therefore, ther e is a dearth of tools for supporting the overall managerial process on distributed software development.

\section{Distributed Software Development. Project Management. Systematic Literature Review.}

\section{INTRODUCTION}

Many projects are being developed by professionals spread over different places. In the last decade, it is possible to notice a significant increase in this approach, known as Distributed Software Development (DSD). This popularization of DSD is based on the expectation of: achieving lower production costs, gaining economies of scale, accessing specialized resources, reducing time-to-market, achieving higher quality, increasing proximity to customers, and accessing new markets (Katainen \& Nahar, 2008; Carmel, 1999).

According to Binder (2007), although many organizations have been executing projects with distributed teams, just a few of them have effective established practices on supporting managers and developers working on this novel environment. In addition, Pichler (2007) reports that many distributed project teams are still created as if all their members were working in the same place, ignoring some problems of the distribution. Moreover, DSD projects usually face the same problems of co-localized projects, such as challenging schedules, quality loss, and cost overrun. Therefore, those congenital problems get even more difficult to be addressed in distributed projects. Hence, in order to alleviate these problems, it is essential to adopt a managerial approach, and tools for distributed collaborative work (Komi-Sirviö \& Tihinen, 2005).

This research aims to identify models and tools, reported in reliable scientific reports, effective on supporting the management of distributed software development projects. The method used to achieve this goal was a systematic literature review.

A systematic literature review evaluates and interprets all available research relevant to a particular research question or topic area. It aims to present an evaluation of the literature relative to a research topic by using a rigorous and auditable methodology. This research follows guidelines defined by Kitchenham (2007) and Travassos (2007).

\section{METHODOLOGY}

The first step to perform a systematic literature review is the protocol definition, which must describe the research plan in details. This research protocol is summarized in the following sub-sessions.

\subsection{Research Questions}

The goal of the systematic review is to find evidences in the literature to answer the following questions:

(RQ1) What are the existing models for managing distributed software development?

(RQ2) What are the existing tools which support management activities on distributed software development?

\subsection{Search Terms}

The search terms used in this SLR are summarized in Table 1. 
Table 1: Search Terms

\begin{tabular}{|l|l|}
\hline Population & (Project Management) \\
\hline \multirow{5}{*}{ Intervention } & AND (Distributed software development \\
& OR Global software development \\
& OR Collaborative software development \\
& OR Distributed teams \\
& OR Offshore outsourcing \\
& OR Global software teams \\
& OR ...) \\
\hline \multirow{5}{*}{ Outcome } & AND (Model \\
& OR Framework \\
& OR Tool \\
& OR Software \\
& OR System \\
& OR ...) \\
\hline
\end{tabular}

\subsection{Scientific Sources}

The search was performed only in those search engines and digital libraries available on the Internet and which are available through the Universidade Federal de Pernambuco (Federal University of Pernambuco) online library services: (1) IEEEXplore Digital Library; (2) ACM Digital Library; (3) ScienceDirect; (4) El Compendex; (5) ICGSE 2009 - $4^{\text {th }}$ International Conference on Global Software Engineering (whose papers were not available on the IEEEXplore at the time the initial search as performed).

\subsection{Study Exclusion Criteria}

Studies matching some of the following cases were excluded from the analysis: (1) not available, (2) do not answer any of our research questions, (3) duplicated, and (4) not finished or incomplete.

\subsection{Primary Study Selection Process}

The primary study selection process is described in Table 2.

Table 2: Document Selection Procedure

\begin{tabular}{|c|l|}
\hline $\begin{array}{c}\text { Step } \\
\mathbf{1}\end{array}$ & $\begin{array}{l}\text { Two researchers performed searches in order to identify } \\
\text { potentially relevant studies. Then, the first selection } \\
\text { was made based on reading titles, by excluding those } \\
\text { papers which are clearly not relevant. }\end{array}$ \\
\hline $\begin{array}{c}\text { Step } \\
\mathbf{2}\end{array}$ & The two lists - one from each researcher - were merged. \\
\hline $\begin{array}{c}\text { Step } \\
\mathbf{3}\end{array}$ & $\begin{array}{l}\text { Studies on the resulting list were evaluated, by reading } \\
\text { abstract and conclusion. Then, by using the study } \\
\text { selection criteria, a final list of relevant studies was } \\
\text { created. }\end{array}$ \\
\hline $\begin{array}{c}\text { Step } \\
\mathbf{4}\end{array}$ & $\begin{array}{l}\text { The data was extracted from reading the entire content } \\
\text { of the studies on the final list. }\end{array}$ \\
\hline
\end{tabular}

\subsection{Extraction and Synthesis of Data}

In order to organize the data extraction, analysis and synthesis of this research, we adopted the JabRef tool, which supports customizations, and eases the literature review overall process.

\section{RESULTS}

The first search retrieved 867 studies from the chosen scientific databases. After performing the document selection procedure, 25 relevant articles were selected. Table 3 shows the distribution of these articles among the resources.

Table 3: Sources

\begin{tabular}{|c|c|c|c|c|c|c|}
\hline 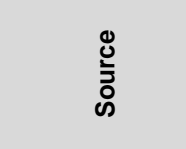 & 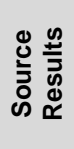 & 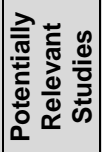 & ¿ $\frac{\overrightarrow{0}}{\frac{\pi}{\sigma}}$ & 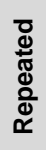 & 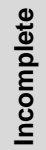 & 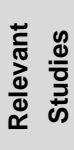 \\
\hline IEEEXplore & 100 & 51 & 31 & 0 & 5 & 15 \\
\hline $\mathrm{ACM}$ & 253 & 33 & 30 & 0 & 1 & 2 \\
\hline ScienceDirect & 100 & 11 & 8 & 0 & 0 & 3 \\
\hline El Compendex & 350 & 19 & 9 & 8 & 0 & 2 \\
\hline ICGSE2009 & 64 & 41 & 34 & 0 & 4 & 3 \\
\hline TOTAL & 867 & 155 & 112 & 8 & 10 & 25 \\
\hline
\end{tabular}

This SLR did not restrict the period of publications, although all selected studies were carried out between 2001 and 2009, as shown in Figure 1, which therefore portraits the relevance this theme has recently acquired.

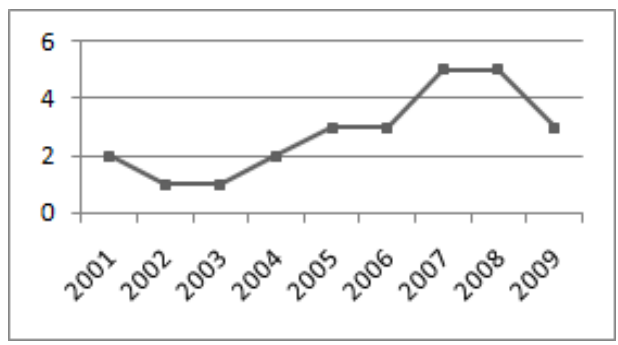

Figure 1: Temporal View

Table 4 shows that among the 25 studies, $12(48 \%)$ are Empirical Studies, 11 (44\%) are Theoretical Studies and 2 (8\%) are Industrial reports. No systematic literature review was identified.

Table 4: Type of Studies

\begin{tabular}{|l|c|c|}
\hline Type of Study & $\#$ & $\%$ \\
\hline Empirical Studies & 12 & $48 \%$ \\
\hline Theorethical Studies & 11 & $44 \%$ \\
\hline Industrial Experience Report & 2 & $8 \%$ \\
\hline Others & 0 & 0 \\
\hline
\end{tabular}

\section{DATA ANALYSIS}

Among the selected studies, this research found relevant evidence to satisfactorily answer the two research questions.

Table 5 presents existing models for managing distributed software development. 
Table 5: Models

\begin{tabular}{|c|c|}
\hline Models & Desciption \\
\hline NEXTMOVE [PS16] & $\begin{array}{l}\text { The NextMove project model allows the task } \\
\text { coordination problem to be described in a } \\
\text { more formal manner. Based on the NextMove } \\
\text { framework, the NextMove distributed project } \\
\text { management tool aims to help project teams in } \\
\text { tracking, coordinating and communicating } \\
\text { tasks in a distributed development } \\
\text { environment. }\end{array}$ \\
\hline TAPER [PS11] & $\begin{array}{l}\text { A generic framework for establishing offshore } \\
\text { development centers that is based on good } \\
\text { practices to overcome these challenges. } \\
\text { TAPER, as the acronym for the five phases of } \\
\text { our framework's methodology: Trust, Assess, } \\
\text { Prove, Enhance, and Reengineer }\end{array}$ \\
\hline CAMEL [PS4] & $\begin{array}{l}\text { The framework CARMEL supports } \\
\text { mechanisms to manage the focus of the } \\
\text { dialogue during the meetings. }\end{array}$ \\
\hline TAMRI [PS13] & $\begin{array}{l}\text { TAMRI (Task Allocation based on Multiple } \\
\text { cRlteria), a tool that can support project } \\
\text { managers in identifying suitable task } \\
\text { allocations in a GSD project planning process. }\end{array}$ \\
\hline Solar System [PS15] & $\begin{array}{l}\text { Each functional organization in a virtual team } \\
\text { is like a planet in solar system, as shown in big } \\
\text { triangles. The key stakeholders compose the } \\
\text { inner circle for communication and } \\
\text { collaboration, while other less key } \\
\text { stakeholders sit in the outer circle. }\end{array}$ \\
\hline $\begin{array}{l}\text { Framework to Enable } \\
\text { Coordination [PS20] }\end{array}$ & $\begin{array}{l}\text { A Framework to Enable Coordination in } \\
\text { Distributed Software Development. The } \\
\text { Information Repository is a centralized store } \\
\text { for data from the various tools. The analysis } \\
\text { engine needs to check adherence to project } \\
\text { policies and issue alerts/advisories as needed. }\end{array}$ \\
\hline $\begin{array}{l}\text { Project Management } \\
\text { Model [PS25] }\end{array}$ & $\begin{array}{l}\text { Spiral type life cycle; Object-oriented system } \\
\text { development process, using UML and UP } \\
\text { specification languages; Incorporation of the } \\
\text { procedural approaching proposed by PMBOK, } \\
\text { expanding the management areas indicated. }\end{array}$ \\
\hline $\begin{array}{l}\text { Conceptual model for } \\
\text { managing an } \\
\text { international IS } \\
\text { development project } \\
\text { [PS12] }\end{array}$ & $\begin{array}{l}\text { The conceptual model consists of } \\
\text { environment, infrastructure, project } \\
\text { management, project participants, } \\
\text { communication, coordination, collaboration, } \\
\text { information sharing tools, artifact sharing tools, } \\
\text { development tools and IS development } \\
\text { process with its start-up, construction and } \\
\text { ending phases. }\end{array}$ \\
\hline $\begin{array}{l}\text { Project management } \\
\text { framework [PS9] }\end{array}$ & $\begin{array}{l}\text { The framework proposed is developed using } \\
\text { Microsoft Project. While Microsoft Project } \\
\text { takes care of most of the scheduling issues, } \\
\text { the discipline of organizing interaction between } \\
\text { various sites in the framework directly enables } \\
\text { the following: Efficient communication between } \\
\text { sites, Multiple views (at a load/release/product } \\
\text { level) of the product, Efficient generation of } \\
\text { project plan for a large product typically } \\
\text { consisting of more than } 200 \text { features. }\end{array}$ \\
\hline $\begin{array}{l}\text { Approach to Offshore } \\
\text { Collaboration [PS5] }\end{array}$ & $\begin{array}{l}\text { Key success factors underlying in model } \\
\text { include: careful setup and planning, knowledge } \\
\text { transfer and training, using a proven Web } \\
\text { delivery foundation (WDF), establishing } \\
\text { policies and procedures, and focusing on } \\
\text { communication and checkpoints. }\end{array}$ \\
\hline $\begin{array}{l}\text { Process Maturity } \\
\text { Framework for } \\
\text { Managing Distributed } \\
\text { Development [PS19] }\end{array}$ & $\begin{array}{l}\text { Distributed process-maturity model features } 24 \\
\text { new key process areas mapped to four } \\
\text { theoretical concepts for distributed work: } \\
\text { mutual knowledge, technology readiness, } \\
\text { collaboration readiness, and coupling in work. }\end{array}$ \\
\hline
\end{tabular}

Table 6 existing tools which support management activities on distributed software development, using a classification adapted from Smith [PS 21].
Table 6: Tools

\begin{tabular}{|c|c|c|}
\hline Type & Focus & Features \\
\hline \multirow{8}{*}{ Synchronous } & \multirow{5}{*}{$\begin{array}{l}\text { Socially } \\
\text { Oriented }\end{array}$} & $\begin{array}{c}\text { Audio conference (Teleconference, } \\
\text { Conference calls or web } \\
\text { conference) [PS2], [PS3], [PS6], } \\
\text { [PS7], [PS14], [PS17], [PS21], } \\
\text { [PS22], [PS24] }\end{array}$ \\
\hline & & $\begin{array}{c}\text { Phone [PS3], [PS6], [PS10], } \\
\text { [PS15], [PS21] }\end{array}$ \\
\hline & & $\begin{array}{c}\text { Videoconference [PS3], [PS6], } \\
\text { [PS7], [PS14], [PS15], [PS17], } \\
\text { [PS18], [PS21], [PS24] }\end{array}$ \\
\hline & & $\begin{array}{c}\text { NetMeeting [PS3], [PS6], [PS14], } \\
\text { [PS23] }\end{array}$ \\
\hline & & $\begin{array}{c}\text { Messenger or chat [PS2], [PS6], } \\
\text { [PS15], [PS17], [PS18], [PS22], } \\
\text { [PS23], [PS24] }\end{array}$ \\
\hline & \multirow{3}{*}{$\begin{array}{l}\text { Information } \\
\text { Exchange } \\
\text { Oriented }\end{array}$} & Eletronic meeting systems [PS21] \\
\hline & & $\begin{array}{c}\text { Virtual whiteboards [PS17], [PS21], } \\
\text { [PS23] }\end{array}$ \\
\hline & & Data conferencing [PS21], [PS23] \\
\hline \multirow{13}{*}{ Asynchronous } & \multirow{3}{*}{$\begin{array}{l}\text { Socially } \\
\text { Oriented }\end{array}$} & Voicemail [PS21] \\
\hline & & Electronic bulletin boards [PS21] \\
\hline & & Forums [PS21] \\
\hline & \multirow{10}{*}{$\begin{array}{l}\text { Information } \\
\text { Exchange } \\
\text { Oriented }\end{array}$} & $\begin{array}{c}\text { Team Intranet websites [PS2], } \\
\text { [PS3], [PS14], [PS21] }\end{array}$ \\
\hline & & Photo gallery [PS 10] \\
\hline & & Wiki [PS1], [PS15], [PS24] \\
\hline & & $\begin{array}{c}\text { E-mail [PS3], [PS6], [PS7], [PS14], } \\
\text { [PS15], [PS18], [PS21], [PS22], } \\
\text { [PS24] }\end{array}$ \\
\hline & & $\begin{array}{c}\text { Change management system] } \\
\text { [PS10], [PS24] }\end{array}$ \\
\hline & & PowerPoint presentations [PS14] \\
\hline & & CVS [PS15] \\
\hline & & Group calendars [PS21], [PS23] \\
\hline & & Nor-real-time databases [PS21] \\
\hline & & Fax [PS3], [PS6] \\
\hline \multirow{3}{*}{$\begin{array}{l}\text { Synchronous/ } \\
\text { Asynchronous }\end{array}$} & \multirow{3}{*}{$\begin{array}{c}\text { Project } \\
\text { Management }\end{array}$} & JIRA [PS22] \\
\hline & & NEXTMOVE [PS16] \\
\hline & & TeamSpace [PS8] \\
\hline
\end{tabular}

\section{FINAL CONSIDERATIONS}

This research aimed to identify effective models and tools for managing Distributed Software Develop ment. Therefore, it is possible to notice that since 2000, the number of studies on DSD has increased, while only few tools have been developed. Moreover, most of the identified tools rely on simple communication features, such as e-mail and chat. Consequently, there is a dearth of tools for supporting managerial process on distributed software development. However, accessing only five sources can be considered a threat to validity of his research, because many other sources seem to be relevant but, due to access restrictions, their papers could not be retrieved and analyzed. Future research must address this problem. Finally, models and tools for DSD still need further research with respect to integration of features and larger coverage of the issues that are novel in DSD with respect to co-located development. 


\section{REFERENCES}

Binder, J. C. (2007). "Global Project Management: Communication, Collaboration and Management Across Borders". Gower Publishing.

Carmel, E. (1999). "Global Software Teams - Collaborating Across Borders and Time-Zones" Prentice Hall, EUA.

Katainen, T. \& Nahar, N. (2008). "Using methods and IT tools innovatively for the management of International IS development projects" Proc. Portland International Conference on Management of Engineering. Technology PICMET 2008, 1851-1863.

Kitchenham, B. (2007) "Guidelines for performing Systematic Literature Reviews in Software Engineering", V 2.3 EBSE Technical Report, EBSE-2007-01.

Komi-Sirviö, S.; Tihinen M. (2005) "Lessons Learned by Participants of Distributed Software Development" Journal Knowledge and Process Management, v. 12 no 2 p. 108-122. Pichler, H. (2007) "Be successful, take a hostage or outsourcing the outsourcing Manager". Proc. Second IEEE International Conference on Global Software Engin eering, ICGSE, 156-161.

Travassos, G., Biolchini J. (2007) "Revisões Sistemáticas Aplicadas a Engenharia de Software" Brazilian Symposium on Software Engineering, João Pessoa, PB, Brasil.

\section{APPENDIX: PRIMARY STUDIES}

[PS1] Bass, M.; El Houda, Z.; Cataldo, M.; Herbsleb, J. D. \& Bass, L. 2006 "Siemens Global Studio Project: Experiences Adopting an Integrated GSD Infrastructure" Proc. International Conference on Global Software Engineering ICGSE '06, 203-212.

[PS2] Battin, R. D.; Crocker, R.; Kreidler, J. \& Su bramanian, K. 2001 "Leveraging resources in global software development" IEEE Softaware, 18, 70-77.

[PS3] Casey, V. \& Richardson, I. 2006 "Project Management within Virtual Software Teams" Proc. International Conference on Global Software Engineering ICGSE '06, 33-42.

[PS4] Cataldo, M.; Shelton, C.; Choi, Y.; Huang, Y.-Y.; Ramesh, V.; Saini, D. \& Wang, L. -Y. , 2009 "CAMEL: A Tool for Collaborative Distributed Software Design" Proc. Fourth IEEE International Conference on Global Software Engineering ICGSE 2009, 83-92.

[PS5] Cusick, J. \& Prasad, A. 2006 " A Practical Management and Engineering Approach to Offshore Collaboration" IEEE Software, 23, 20-29.

[PS6] Deshpande, S. \& Richardson, I. 2009 "Management at the Outsourcing Destination - Global Software Development in India" Proc. Fourth IEEE International Conference on Global Software Engineering ICGSE 2009, 217-225.

[PS7] Evaristo, J.; Scudder, R.; Desouza, K. \& Sato, O. 2004 "A dimensional analysis of geographically distributed project teams: a case study" Journal of Engineering and Technology Management, Elsevier.

[PS8] Geyer, W.; Richter, H.; Fuchs, L.; Frauenhofer, T.; Daijavad, S. \& Poltrock, S. 2001 "A team collaboration space supporting capture and access of virtual meetings" GROUP '01: Proceedings of the 2001 International ACM SIGGROUP Conference on Supporting Group Work, ACM, 188-196.

[PS9] Ghosh, P. P. \& Varghese, J. C. 2004 "Globally distributed product development using a new project management framework" International Journal of Project Management, Elsevier.
[PS10] Herbsleb, J. D.; Paulish, D. J. \& Bass, M. 2005 "Global software development at Siemens: experience from nine projects" Proc. 27th International Conference on Software Engineering ICSE 2005, 524-533.

[PS11] Hofner, G. \& Mani, V. S. 2007 "TAPER: A generic framework for establishing an offshore development center" Proc. Second IEEE International Conference on Global Software Engineering ICGSE 2007, 162-172.

[PS12] Katainen, T. \& Nahar, N. 2008 "Using methods and IT tools innovatively for the management of International IS development projects" Proc. Portland International Conference on Management of Engineering. Technology PICMET 2008, 1851-1863.

[PS13] Lamersdorf, A. \& Munch, J. 2009 "TAMRI: A Tool for Supporting Task Distribution in Global Software Development" Projects Proc. Fourth IEEE International Conference on Global Software Engineering ICGSE 2009, 322-327.

[PS14] Lee-Kelley, L. \& Sankey, T. 2008 "Global virtual teams for value creation and project success: A case study" International Journal of Project Management, Elsevier.

[PS15] Liang, X.; Ma, X.; Yang, Q.; Zhuo, Y.; Xu, B. \& Ma, A. 2008 "A Virtual Human Resource Organization Model in Dual-Shore Collaborative Software" Development Proc. 4th International Conference on Wireless Communications, Networking and Mobile Computing WiCOM '08, 1-5.

[PS16] Mak, D. K. M., Kruchten, P. B. 2007 "NextMove: A Framework for Distributed Task Coordination" Proc. 18th Australian Software Engineering Conference ASWEC 2007 , 399-408.

[PS17] Nidiffer, K. E. \& Dolan, D. 2005 "Evolving distributed project management" IEEE Software, 22, 63-72.

[PS18] Ralyte, J.; Lamielle, X.; Arni-Bloch, N. \& Leonard, M. 2008 "A Framework for supporting management in distributed information systems development" Proc. Second International Conference on Research Challenges in Information Science RCIS 2008, 381-392.

[PS19] Ramasubbu, N.; Krishnan, M. S. \& Kompalli, P. 2005 "Leveraging global resources: a process maturity framework for managing distributed development" IEEE Software, 22, 80-86.

[PS20] Sinha, V. S.; Sengupta, B. \& Ghosal, S. 2007 "An Adaptive Tool Integration Framework to Enable Coordination in Distributed Software Development" Proc. Second IEEE International Conference on Global Software Engineering ICGSE 2007, 151-155.

[PS21] Smith, P. \& Blanck, E. 2002 "From experience: leading dispersed teams" Journal of Product Innovation Management, europa.com.

[PS22] Sutherland J., Viktorov A., Blount J., Puntikov N., 2007 "Distributed Scrum: Agile Project Managem ent with Outsourced Development Teams". Proceedings of the 40th Hawaii International Conference on System Sciences - 2007. IEEE Computer Society.

[PS23] Thissen, M. R.; Page, J. M.; Bharathi, M. C. \& Austin, T. L. 2007 "Communication tools for distributed software development teams" SIGMIS-CPR '07: Proceedings of the 2007 ACM SIGMIS CPR conference on Computer personnel research, ACM, 28-35.

[PS24] Young, C. \& Terashima, H. 2008 "How Did We Adapt Agile Processes to Our Distributed Development?" Proc. Conference Agile AGILE '08, 304-309.

[PS25] Zanoni, R. \& Audy, J. L. N. 2003 "Project management model for a physically distributed software development environment" Proc. 36th Annual Hawaii International Conference on System Sciences, 8pp. 